further half truths grow up around this fraught subject.

RICHARD FRY

Department of Mental Health Sciences.

St George's Hospital.

London

Department of Public Health Medicine

RUTH WALLIS

and Epidemiolog

King's College Hospital,

London

1 Arnold RP, Rogers D, Cook DAG. Medical problems of adults who were sexually abused in childhood. Br. Med f 1990:300: 705-8. (17 March )

2 Sedney M, Brooks B. Factors associated with a history of childhood sexual experience in a non-clinical female population. Fournal of the American Academy of Child Psychiatr 1984;23:215-8.

3 Briere J, Runtz M. Symptomatology associated with childhood sexual victimisation in a non-clinical adult sample. Child Abuse and Neglect 1988;12:51-9.

+ Bagley C. Rainsay R Sexual abuse in childhood: psychosocial outcomes and implications for social work practice. Foumal of outcomes and implications for social work practice.
Social Work and Human Sexuality 1985;4:33-47.

5 Mullen PE, Romans-Clarkson SE, Walton VA, Herbison GP. Impact of sexual and phisical abuse on women's mental Impact of sexual and phy
health. Lancet 1988;i:841-5.

6 Shepherd M, Cooper B, Brown AC, Kalton G. Psychiatric illness in general practice. Oxford: Oxford University Press, 1966.

7 Croft-Jeffreys C, Wilkinson (i. Estimated costs of neurotic disorder in UK general practice 1985. Psychol Med 1990;19: 549-58

8 Ribberink ML, Slurink GE, Everaerd W, Hanewald G. The incidence of sexual violence among women with gynecological complaints. Fournal of Psychosomatic Obstetrics and Gynaecologv 1989;10( (suppl 1):25.

9 Finkelhor D, ed. A sourcebook on child sexual abuse. Beverly Hills, California: Sage, 1986

10 Bachmann GA, Moeller TP, Benett J. Childhood sexual abuse and the consequences in adult women. Obstet Gynecol 1988; 71:631-42.

11 Lindberg FH, Distad LJ. Post-traumatic stress disorders in women who experienced childhood incest. Child Abuse and Neglect 1985;9:329-34.

12 Gross RJ, Doerr H, Caldirola D, Guzinski G, Ripley H. Borderline syndrome and incest in chronic pelvic pain patients. Int f Psychiatry Med 1981;10:79-96.

13 Walker E, Katon W, Harrop-Griffiths J, Holm L, Russo J, Hickock LR. Relationship of chronic pelvic pain to pswchiatric diagnoses and childhood sexual abuse. $A m f$ Psychiatry 1988;145:75-80.

14 Raskin DE. Diagnosis in patients with chronic pelvic pain. Am 7 Psvchiatry 1984;141:824.

15 Russell DEH. The secret trauma: incest in the lives of girls and women. New York: Basic Books, 1986

SIR,-Dr R P Arnold and colleagues have described the incidence of medical problems in adults who were sexually abused during childhood. ' They emphasise the increased incidence of somatisation in these adults. This concept is crucial for those who care for patients with epilepsy as illustrated by our recent experience of adolescent or young adult females presenting with ostensibly poorly controlled "epilepsy." We have now seen five such patients, who were eventually found to be suffering from psychogenic pseudoseizures rather than true epilepsy. Subsequent inquiry disclosed a history of sexual abuse during childhood in each patient. This was particularly clear in the two cases described below.

A 17 year old girl had been diagnosed as having epilepsy at the age of 13 years. She was admitted four years later as it had not been possible to achieve adequate control of the attacks as an outpatient. The attacks were of two types. The first consisted of sudden loss of consciousness with urinary incontinence but without a clonic phase. The second was characterised by a generalised clonic phase and urinary incontinence withou complete loss of consciousness. She had stopped bedwetting only at the age of 5 years and had developed secondary enuresis at the age of 10 . Full investigation including computed tomography showed no abnormality. Electroencephalography showed some bitemporal slow wave activity with occasional sharp wave transients. Ambulatory electroencephalography yielded normal results even during an "attack" associated with urinary incontinence. It therefore seemed that the attacks were predominantly psychogenic pseudoseizures, and inquiries were made into her social background. These interviews disclosed that she had been sexually abused by her brother from the age of 8 and also in later years by her grandfather. After these disclosures and appropriate counselling the attacks largely resolved.

A 25 year old woman presented with a 12 year history of poorly controlled epilepsy. The attacks of altered consciousnesss with urinary incontinence had resolved at the age of 18 only to recur at the age of 20 . They once again remitted but came back three years later, remaining poorly controlled until she was seen. The computed tomogram was normal. She reported attacks during 24 hours of ambulatory electroencephalography, but there were no corresponding correlates in the electroencephalogram. She complained of continuing attacks while in the ward, none of which were ever apparent to the nursing staff. We thought that these attacks were pseudoseizures. Detailed inquiry subsequently disclosed that she had been sexually abused at the age of 10 by an elderly male neighbour, who undressed her and lay on top of her simulating intercourse. At the age of 20 she met her fiancé and soon began having intercourse. Three years later she was assaulted by an uncle who penetrated her vagina digitally. The number of attacks fell abruptly after the disclosure of these facts.

These two cases illustrate the common clinical problem of differentiating non-organic pseudoseizures from true epilepsy. Detailed investigation and extensive manipulation of treatment was performed in both cases without obtaining adequate control of the attacks. Although the urinary incontinence was initially thought to favour an organic origin for the seizures, it was in fact enuretic rather than epileptic. Enuresis is common in sexually abused children. ${ }^{2}$ Several interviews were needed to elicit the full background. The second was the most productive of factual information, the first tending to prepare the ground and build confidence to share distressing material. This experience shows the importance of a team approach, the physician, psychologist, and medical social worker combining to devise a suitable line of treatment.

Although we have reported on only two patients in detail, we suspect that this might be a more widespread problem than previously realised. Our cases show further aspects of the delayed sequelae of childhood sexual abuse during adult life and emphasise the importance of detecting such abuse at an early stage and depriving the abusers of access to the child at the earliest possible opportunity.

J D MITCHELI

H N GIBSON

Royal Preston Hospital

Preston PR2 +H'T

1 Arnold RP, Rogers D, Cook DAG. Medical problems of adult: who were sexually abused in childhood. $\mathrm{Br}$ Med 7 1990; 300:705-8. 17 March.

2 Skuse DH. Emotional abuse and neglect. Br Med $\mathcal{F} 1989$ 298: 1692-4.

\section{Attitudes to viability of preterm infants}

SIR, - The study from the Trent region by Dr A C Fenton and colleagues of variability from unit to unit in attitudes to the viability of preterm infants showed that this variability had an impact on the reporting of perinatal deaths.' The authors concluded that there would be advantages in introduc ing the World Health Organisation's recommendation that all births and deaths of fetuses weighing $\geqslant 500 \mathrm{~g}$ should be registered. ${ }^{2}$

The Office of Population Censuses and Surveys discussed possible changes in criteria for registration of stillbirths in its white paper Registration
Proposals for Change." This was published the previous month and reported on the results of a consultation for changes in the law about the registration of births, marriages, and deaths that were set out in an earlier green paper Registration: Modern Service. 'The green paper asked for views about whether separate legislation should be introduced to change the current legal definition of stillbirth by reducing the current gestational age limit of 28 weeks.

The white paper reported that "There were 102 responses on this issue, both from individuals and from a wide variety of organisations in the medica field. Virtually all favoured gestational age as a means of defining stillbirths, with no significant support for birthweight."' This is hardly surprising as the possibility of using birth weight was not mentioned in the green paper. As a consequence i is unlikely that anyone without prior knowledge of World Health Organisation definitions would have put them forward as a basis for future legislation.

The differences reported in the Trent region exist to a much larger extent internationally as countries differ in the criteria used in their legislation about the registration of live births, stillbirths, and infant deaths. The World Health Organisation's recommendations were drawn up with the aim of encouraging countries to change their legislation so that comparable statistics can be produced. If England and Wales retain gestational age without birth weight as the sole criterion for stillbirth registration we will lose the opportunity to do so.

ALISON MACFARLANE

National Perinatal Epidemiology Unit,

Radcliffe Infirmary

Oxford OX2 6HE

I Fenton AC, Field DJ, Mason E, Clarke M. Attitudes to riabilit of preterm infants and their effect on figures for perinata mortality. Br.Med f 1990;300:434-6. (17 February

2 World Health Organisation. International classificution of diseases. injuries and causes of death. Ninth revision. WHO: Geneva, 1978.

Office of Population Censuses and Survers. Registration: proposals for change. London: HMSO, 1990. (Cmnd 939

Office of Population Censuses and Survers. Registration: modern service. London: HMSO, 1988.

\section{Community care}

SIR,-Further to Dr Michael Ashley-Miller's editorial,' I should like to describe the experience of Leicestershire District Health Authority in one aspect of providing community care. For three years we have been offering a medical examination to handicapped adults. Long serving clinical medical officers, who are members of community mental health teams and have experience of screening and surveillance of the developing child, do the medicals. Liaison meetings are held with the family practitioner committee and with representatives of the relevant paramedical professions.

The known population of handicapped adults in Leicestershire is 2100 . With 320 sessions a year we offer a three yearly medical, with earlier review if necessary. These take place countywide, in day centres, technical colleges, and long stay hospitals.

A letter of invitation is sent to the patients, ${ }^{2}$ and carers are invited to attend. The patient's general practitioner is notified of all baseline data and any abnormal findings. (Inpatients of more than two years' duration have no general practitioner - this is seen as a disadvantage.) Medical advice is offered to staff when this is in the interest of the patient. All data are entered on to the computer and form part of the mental handicap register, which is to be used for long term planning.

An evaluation of the service-in terms of referrals - was carried out on $10 \%$ of 1340 casenotes. In 134 patients, 59 referrals were made: a $44 \%$ referral rate. Some patients were referred to more than one 